\title{
Model dan Kewenangan Komisi Yudisial: Komparasi dengan Bulgaria, Argentina, Afrika Selatan, dan Mongolia ${ }^{1}$
}

\author{
Idul Rishan dan Abel Putra Hamonangan Pangaribuan \\ Fakultas Hukum Universitas Islam Indonesia \\ Jln.Tamansiswa No 158 Yogyakarta \\ idul.rishan@uii.ac.id; Abelputrahp@gmail.com
}

Received: 3 Mei 2017; Accepted: 31 Mei 2017; Published: 28 Februari 2018

DOI: 10.20885/iustum.vol24.iss3.art1

\begin{abstract}
This study examined the comparison of models and authorities of judicial councils in Bulgaria, Argentina, South Africa, and Mongolia as well as its analysis on the Judicial Commission (KY) of Indonesia. This was a juridical-normative research that used statute approach, case approach, and comparative approach. The results showed that, first, based on the comparison results of the four countries (Bulgaria, South Africa, Argentina and Mongolia), KY in Indonesia was established on the same basis. This can be seen from the guarantee of judicial independence in the constitution, the judicial council arrangement in constitutional level, the same reason of establishment, similar authorities and institutional models, as well as partisan composition. Second, the comparative analysis has mapped the differences related to the models and authorities of $K Y$ and those of the judicial councils in these four countries. Such differences can be seen in terms of the number and model of group representation in the composition of KY membership. Besides, the authority of KY is relatively very small and limited if compared to that of these judicial councils.
\end{abstract}

\section{Keywords: Model; Authority; Judicial Commission of Indonesia; Judicial Council}

\section{Abstrak}

Penelitian ini mengkaji perbandingan model dan kewenangan judicial council di Bulgaria, Argentina, Afrika Selatan, dan Mongolia serta analisisnya terhadap Komisi Yudisial (KY) di Indonesia. Jenis penelitian ini yuridis normatif. Pendekatan yang digunakan ialah pendekatan perundang-undangan, pendekatan kasus, dan pendekatan komparatif. Hasil penelitian menunjukkan, Pertama berdasarkan hasil komparisi di empat negara (Bulgaria, Afrika Selatan, Argentina dan Mongolia), KY di Indonesia lahir atas kecenderungan yang sama. Titik persamaan itu dapat dilihat dari adanya jaminan independensi peradilan dalam konstitusinya, pengaturan judicial council di dalam level konstitusi, faktor pendorong kelahiran yang sama, kemiripan corak kewenangan, dan kemiripan model kelembagaan serta komposisi keanggotaan yang bersifat partisan. Kedua, analisis perbandingan berhasil memetakan titik perbedaan model dan kewenangan KY dengan judicial council di empat negara. Pembedaan itu dapat diidentifikasi dari segi jumlah dan model keterwakilan golongan dalam komposisi keanggotaan $\mathrm{KY}$. Selain itu, daya jelajah kewenangan KY relatif sangat kecil dan terbatas jika dibandingkan dengan judicial council yang menjadi sumber komparasi.

Kata-kata Kunci: Model; Kewenangan; Komisi Yudisial RI; Judicial Council

${ }^{1}$ Riset ini didanai oleh DPPM UII dengan Judul "Perbandingan Judicial Council: Anotasi terbadap Model dan Kewenangan KY di Indonesia”, DPPM UII, Yogyakarta, 2017. 


\section{Pendahuluan}

Sebuah working group yang disponsori oleh dana bantuan Amerika Serikat (IFES) merilis sebuah laporan hasil penelitian komparatif mereka terhadap institusi Komisi Yudisial (KY) di beberapa negara. Pada pengantar laporannya IFES menyatakan, dalam rangka membangun peradilan yang independen dan akuntabel, banyak negara telah memilih untuk menciptakan lembaga baru seperti KY. Kewenangan KY dapat memainkan peran penting dalam memperkuat independensi peradilan, dan dalam menciptakan mekanisme akuntabilitas peradilan. Institusi ini hadir sebagai salah satu komponen dari strategi reformasi peradilan yang luas, yang juga mencakup berbagai isu, termasuk akses keadilan, penegakan hukum, dan anti korupsi. ${ }^{2}$

Sampai 2004 saja, 43 negara (termasuk Indonesia) telah mengatur KY dalam konstitusinya. ${ }^{3}$ Kemudian laporan Chicago University pada 2008, KY telah berkembang hingga 121 negara di dunia.4 Dengan penamaan lembaga dan kewenangan yang beragam, organ ini bertujuan untuk meningkatkan independensi peradilan. Di negara-negara Uni Eropa, KY dibentuk untuk memberikan sumbangsih kualitas independensi peradilan, meningkatkan efisiensi administrasi dan manajerial peradilan. ${ }^{5}$ Di Amerika Latin, KY dibentuk untuk menjaga independensi peradilan dari intervensi pemerintah dan parlemen, serta meningkatkan fungsi peradilan dengan menggunakan mekanisme pengawasan independen (independent oversight mechanism). ${ }^{6}$ Begitu juga di Asia dan Afrika, KY telah berkembang sebagai balancing dalam kekuasaan kehakiman.

Latar belakang pembentukan KY di berbagai negara tersebut sebagai akibat dari salah satu atau lebih dari lima hal berikut ini: (a) lemahnya monitoring intern (b) ketiadaan lembaga penghubung antara kekuasaan pemerintah dan kekuasaan

2 IFES 2004 kemudian dikutip oleh, Imam Anshori Saleh, Konsep Pengawasan Kehakiman; Upaya Memperkuat Kewenangan Konstitusional Komisi Yudisial Dalam Pengawasan Peradilan, Setara Press, Malang, 2014, hlm. 179.

${ }_{3}^{3}$ A. Ahsin Thohari, Komisi Yudisial \& Reformasi Peradilan, ELSAM, Jakarta, 2004, hlm. 106.

${ }^{4}$ Nuno Garoupa dan Tom Ginsburg, "Guarding the Guardians: Judicail Councils and Judicial independence", John M. Olin Law and Economic Working Paper No. 444, Public Law and Legal Theory Working Paper No. 250, Chicago, 2008, hlm. 26.

5 Wim Voermans, Komisi Yudisial di beberapa negara Uni Eropa (Council for the Judiciary in EU Countries), Lembaga Kajian dan Advokasi untuk Independensi Peradilan (LeIP), Jakarta, 1999, hlm. 6

${ }^{6}$ Emilio J Cardenas dan Hector M. Chaver, "Corruption, Accountability and Discipline of Judges in Latin America", Comparative of Analysis of Judicial Corruption, Transparency Internasional; Cambridge University Press, 2007, hlm. 45-46. 
kehakiman; (c) persoalan teknis non hukum yang membebani lembaga peradilan; (d) tidak adanya konsistensi lembaga peradilan, karena setiap putusan kurang memperoleh penilaian dan pengawasan yang ketat dari sebuah lembaga khusus; (e) pola rekruitmen hakim selama ini dianggap terlalu bias dengan masalah politik. ${ }^{7}$

Di Indonesia kehadiran KY dalam rumpun kekuasaan kehakiman, sebenarnya justru dilatarbelakangi apa yang disebut oleh penulis sebagai gejala reaksional. Dikatakan sebagai gejala reaksional karena pertama; terdapat reaksi kekecewaan yang cukup akumulatif terhadap independensi peradilan di Indonesia. Sebastian Pompe misalnya, secara terang-terangan membuka sejarah kelam independensi peradilan di Indonesia dalam disertasinya yang berjudul The Indonesian Superme Court; A Study of Institutional Collapse.

Terungkap pada masa setelah kemerdekaan, Soekarno pada saat itu kerap mengintervensi perkara-perkara tertentu dalam proses peradilan. Lebih lanjut pada masa orde baru Soeharto dengan kooptasi politiknya terhadap jabatan ketua Mahkamah Agung (MA). ${ }^{8}$ Imbasnya justru memunculkan public distrust yang cukup kuat terhadap dunia peradilan. Kedua pengaruh global yang cukup kuat memengaruhi bangsa Indonesia dalam mengembangkan institusi sejenis judicial commission. Kehadiran KY di Indonesia, bukanlah hajat elit politik, melainkan hajat rakyat. Rakyat yang telah menahan diri dalam kesabaran hampir empat dekade dan selalu dijadikan korban (victim) oleh pelaku mafia peradilan. ${ }^{9}$

Dalam Pasal 24B ayat (1) UUD 1945, menyatakan KY bersifat mandiri dan memiliki wewenang untuk mengusulkan pengangkatan hakim agung dan wewenang lain dalam rangka menjaga dan menegakan kehormatan, keluhuran martabat, serta perilaku hakim. ${ }^{10}$ Dua kewenangan konstitusional KY pada prinsipnya bertujuan untuk meningkatkan mutu independensi peradilan melalui

\footnotetext{
${ }^{7}$ Ni'matul Huda, Lembaga Negara Dalam Masa Transisi Demokrasi, UII Press, Yogyakarta, 2007, hlm. 149.

8 Sebastian Pompe, Runtubnya Institusi Mabkamah Agung, Lembaga Kajian dan Advokasi Untuk Independensi Peradilan, Jakarta, 2012, hlm. 98 dan 165. hlm. ii.

${ }_{9}^{9}$ Busyro Muqaddas, Dalam Pengantar Cetak Biru Pembaruan Komisi Yudisial 2010-2025, KYRI, Jakarta, 2010,

${ }^{10}$ Lihat Pasal 24B ayat (1) UUD RI 1945.
} 
sistem recruitment hakim, dan mutu akuntabilitas peradilan dalam menjaga dan menegakkan kehormatan, keluhuran martabat serta perilaku hakim.

Sebagai produk lembaga negara yang lahir dalam masa transisi demokrasi, sejak awal berdirinya bahkan sampai dengan saat ini, kewenangan KY menuai banyak polemik ketika berhadapan dengan pelaku utama kekuasaan kehakiman. Tidak jarang resistensi dari MA maupun Mahkamah Konstitusi (MK) harus bermuara pada putusan uji materi lembaga peradilan. Sebagai the sole interpreter of constitution, besar kemungkinan MK mengubah karakteristik KY selama kurang lebih satu dekade ini.

Sebagai contoh, terdapat empat putusan uji materi yang secara signifikan berpengaruh pada model dan kewenangan KY. Pertama, di 2006 terdapat Putusan MK Nomor 005/PUU-IV/2006. Putusan ini cenderung kompromistis sebab MK melepas diri dari subjek pengawasan KY. ${ }^{11}$ Kedua, pada tahun 2011 terdapat Putusan MA Nomor 36/PUU/2011 yang membatalkan beberapa butir kode etik pengawasan perilaku hakim sebagaimana yang telah disepakati oleh KY dan MA. ${ }^{12}$

Ketiga, pada 2013 terdapat Putusan MK Nomor 1-2/PUU-XII/2014. Putusan ini berhasil membatalkan seluruh materi muatan dalam Perppu MK dengan menganulir kewenangan KY membentuk panel ahli seleksi hakim konstitusi dan pelibatan KY dalam pembentukan majelis kehormatan hakim konstitusi. ${ }^{13}$ Keempat, pada 2015, terdapat Putusan MK Nomor 43/PUU-XIII/2015. MK menganulir kewenangan KY dalam melakukan seleksi bersama dengan MA terhadap seleksi hakim karir. ${ }^{14}$

Rentetan panjang terhadap pelemahan kewenangan KY telah membawa diskursus baru terhadap eksistensi KY dalam praktik ketatanegaraan di Indonesia. Sebab sebagai anak kandung reformasi, KY telah mengalami banyak pergeseran kewenangan secara komperhensif dengan adanya empat fase uji materi di MA maupun MK. Tentunya menjadi kajian yang menarik untuk diteliti. Perlu ada studi tersendiri untuk melakukan komparisi terhadap model dan kewenangan Judicial Council di berbagai negara. Hipotesis awal mendudukkan kewenangan KY saat ini

\footnotetext{
11 Lihat Putusan MK Nomor 005/PUU-IV/2006.

12 Lihat Putusan MA Nomor 36/PUU/2011.

13 Lihat Putusan MK Nomor 12/PUU-XII/2014.

${ }^{14}$ Lihat Putusan MK Nomor 43/PUU-XIII/2015.
} 
relatif sangat kecil. Pengayaan terhadap komparisi di berbagai negara tentunya dapat membantu untuk mengidentifikasi langkah yang patut dilakukan ke depan terhadap model dan kewenangan KY di Indonesia.

\section{Rumusan Masalah}

Berdasarkan latar belakang di atas, maka dirumuskan masalah yang akan dikaji yaitu bagaimana model dan kewenangan judicial council di Bulgaria, Argentina, Afrika Selatan, dan Mongolia, serta bagaimana analisis perbandingannya terhadap KY di Indonesia?

\section{Tujuan Penelitian}

Penelitian ini bertujuan untuk memperoleh dua hal. Pertama mengenai model dan kewenangan Judicial Council council di Bulgaria, Argentina, Afrika Selatan, dan Mongolia dan kedua, analisis perbandingannya dengan Komisi Yudisial di Indonesia.

\section{Metode Penelitian}

Metode penelitian yang dipakai dalam penelitian ini adalah metode penelitian kualitatif. Penelitian ini merupakan penelitian yuridis normatif. ${ }^{15}$ Pendekatan yang dipakai antara lain statue approach, case approach, dan comparative approach. ${ }^{16}$ Pendekatan komparatif dilakukan terhadap judicial council di empat negara antara lain Bulgaria, Argentina, Afrika Selatan, dan Mongolia. Ke empat negara dipilih berdasarkan empat aspek yaitu (1) jaminan independensi peradilan dalam konstitusinya, (2) Pengaturan judicial council di dalam level konstitusi (3) faktor pendorong kelahiran yang sama dengan KY di Indonesia (4) kemiripan corak kewenangan dengan KY di Indonesia dan (5) kemiripan model kelembagaan serta komposisi keanggotaan KY di Indonesia. Data yang dipakai adalah data sekunder. Bahan yang digunakan dalam penelitian ini adalah bahan primer, sekunder dan tersier. ${ }^{17}$

\footnotetext{
${ }^{15}$ F. Sugeng Istanto, Penelitian Hukum, Cv Ganda, Yogyakarta, 2007, hlm. 29.

16 Peter Mahmud Marzuki, Penelitian Hukum, Kencana Prenada, Media Group, Jakarta, 2005, hlm. 29.

${ }^{17}$ Soerjono Soekanto, Pengantar Penelitian Hukum, UI Press, Jakarta, 1986, hlm. 51.
} 


\section{Hasil Penelitian dan Pembahasan}

\section{Judicial Council di 4 Negara}

\section{Bulgaria}

Dalam konstitusi Bulgaria, pengaturan mengenai kekuasaan kehakiman diatur pada Bab VI dengan judul "Judicial Power". Di dalam Konstitusi Bulgaria, jaminan atas independensi peradilan mendapatkan porsinya dalam bab yang sama. Pasal 117 ayat (2) menyatakan: "The judicial branch is independent. In the performance of their functions, all judges, court assessors, prosecutors, and investigating magistrates shall be subservient only to the law" ${ }^{18}$

Jaminan independensi peradilan yang diakui Pemerintahan Bulgaria tidak hanya berimbas secara kelembagaan dan fungsional, melainkan juga berimbas pada otonomi administrasi budgeting kehakiman. Pasal 117 ayat (3) menyatakan: "the judicial branch of government shall have an independent budget."19 Penegasan komitmen jaminan independensi peradilan Bulgaria merupakan hasil resultante politik reformasi konstitusi di 1991.

Reformasi konstitusi Bulgaria di 1991 tidak hanya berimbas pada jaminan independensi peradilan tetapi juga berimplikasi pada pelembagaan organ sejenis Komisi Yudisial dengan penamaan Supreme Judicial Council (SJC). SJC diatur secara tegas dalam Konstitusi Bulgaria tepatnya pada Pasal 130 Konstitusi Bulgaria. Faktor pendorong kelahiran SJC di Bulgaria dipicu oleh pengalaman pahit di rezim komunis. Di bawah rezim komunis kekuasaan kehakiman bukan menjadi variabel yang independen. Seleksi dan pengangkatan hakim tunduk pada kontrol kaum komunis. Imbasnya, proses peradilan tidak dilakukan secara imparsial. ${ }^{20}$

Salah satu kesepakatan politik untuk mewujudkan reformasi peradilan ialah memutus mata rantai kekuasaan eksekutif dalam hal administrasi manajerial peradilan. SJC merupakan pilihan politik saat itu untuk mengawal independensi peradilan. ${ }^{21}$ Komposisi keanggotaan SJC terdiri dari 25 anggota. Tiga di antaranya dijabat secara ex officio oleh Ketua Superme Court of Cassation, Ketua Superme

18 Pasal 117 ayat (2) Konstitusi Bulgaria 1991

19 Pasal 117 ayat (2) Konstitusi Bulgaria 1991

${ }^{20}$ Gerald Zarr, Judicial Strengthening in Bulgaria, Bulgaria Judiciary Project No.: 180-0249.83, United Stated Agency for International Development, Sofia Bulgaria, 1998, hlm. 2

21 Open Society Institute, Judicial Independence in Bulgaria, Europe Project: Monitoring the E.U. Accession Process Judicial Independence, 2001, E.U., hlm. 75. 
Administrative Court, dan Chief Prosecutor. Sebelas anggota lainnya dipilih oleh parlemen, dan sebelas anggota lainnya dipilih dari cabang kekuasaan yudisial. ${ }^{22}$

Kriteria 25 anggota tersebut mempunyai kemampuan kapabilitas, profesional dan berintegritas. Tidak hanya itu para calon anggota wajib mempunyai pengalaman minimal 15 tahun di bidangnya. ${ }^{23}$ Jika dilihat dari komposisi keanggotaanya yang berasal dari beragam golongan (partisan), jumlah keanggotaannya ganjil, pengambilan keputusan bersifat kolektif kolegial dan tidak tunduk pada political will Presiden, maka SJC merupakan komisi negara independen.

Berdasarkan amanat konstitusi SJC mempunyai kuasa dalam mengusulkan kepada Presiden terkait pengangkatan, pemberhentian, mutasi, promosi, dan pembinaan, bagi para hakim dan jaksa. Lebih dari itu, SJC berfungsi sebagai badan otonom administrasi manajerial kehakiman. Sebagai badan administrasi manajerial, SJC menjadi penghubung komunikasi politik antara parlemen dan pemerintah khususnya menteri kehakiman.

\section{Argentina}

Berdasarkan konstitusi Argentina, pengaturan mengenai kekuasaan kehakiman diatur pada Third Division dengan judul “The Judicial Power". Penegasan atas pentingnya jaminan independensi peradilan diatur pada bab yang sama. Pasal 109 Konstitusi Argentina menyatakan: "in no case the President of the Nation shall exercise judicial functions, assume jurisdiction over pending cases, or reopen those already adjudged". 24

Pasal ini memberi penegasan bahwa dalam keadaan apapun Presiden tidak dapat melakukan fungsi mengadili, mengambil alih yurisdiksi atas kasus-kasus yang tertunda, maupun membuka kembali kasus-kasus yang telah diputus lembaga peradilan. Lebih lanjut Forum Regional Amerika Latin memberikan penjelasan bahwa "According to Argentina Constitution, the judiciary is one of the three powers of the state, totally independent from the executive and legislature and its decisions

\footnotetext{
22 Pasal 130 ayat (1) dan (3) Konstitusi Bulgaria 1991

23 Pasal 130 ayat (2) Konstitusi Bulgaria 1991

24 Pasal 109 Konstitusi Argentina 1994.
} 
are not revisable by political organs. ${ }^{25}$ Dari masing-masing klausul di atas maka kemerdekaan kekuasaan kehakiman (independent of judiciary) Argentina dijamin secara tegas dalam konstitusinya.

Reformasi peradilan Argentina (judicial reform) yang dilakukan pada 1994 juga berimplikasi langsung pada tata kelola kehakiman (court administration). Buah reformasi tersebut berhasil melembagakan organ sejenis Komisi Yudisial dalam konstitusinya. Jodi Finkel menyatakan “Argentina's 1994 constitution included important institutional changes that had the potential to reduce executive influence in the judiciary. These changes included a modification of the selection process for court justices and the establishment of a National Judicial Council." 26

National Judicial Council (NJC) diatur dalam Pasal 114 Konstitusi Argentina. Faktor pendorong kelahiran organ negara ini dipicu dengan semangat reformasi peradilan di rezim Presiden Carlos Menem. Menem menyetujui gagasan partai radikal yang menginginkan agar proses seleksi dan pengangkatan hakim diserahkan kepada organ negara independen yang tidak tunduk pada political will Presiden. ${ }^{27}$ Artinya faktor pendorong kelahiran organ negara ini dilakukan untuk meminimalisir kepentingan politik presiden dalam hal pengangkatan hakim di badan peradilan.

Komposisi keanggotaan NJC terdiri dari 13 orang komisioner. 3 di antaranya dipilih dari ikatan organisasi hakim, yang dua berasal dari ibu kota negara dan satu hakim berasal dari provinsi. 6 anggota berasal dari parlemen. Empat di antaranya dari dari partai pendukung pemerintah dan dua dari partai oposisi pemerintah. 4 anggota lainnya berasal dari dua orang pengacara, dan masing-masing anggota lainnya berasal dari pemerintah dan akademisi berlatar belakang profesor. ${ }^{28}$ Jika dilihat dari komposisi keanggotaanya yang berasal dari beragam golongan (partisan), jumlah keanggotaannya ganjil, pengambilan keputusan bersifat kolektif

${ }^{25}$ Latin America Regional Forum, Appointment, Control and Removal of Judges in the Region, LARF-International Bar Association, United Kongdom, 2008, hlm. 1.

${ }^{26}$ Jodi Finkel, Judicial Reform in Argentina in The 1990's: How Electoral Incentives Shape Institutional Change, Research, Loyola Marymount University, 2004, hlm. 67

27 Ibid.

${ }^{28}$ Iveth A. Plascencia, "Judicial Appointments: A Comparative Study of Four Judicial Appointment Models Used by Sovereigns Around the World”, Law School Student Scholarship- Seton Hall Law Paper 666, New Jersey, 2013, hlm. 16-17. 
kolegial dan tidak tunduk pada political will presiden, maka NJC merupakan komisi negara independen.

Berdasarkan Pasal 114 ayat (3) konstitusi, NJC mempunyai wewenang melakukan seleksi hakim berdasarkan uji kompetensi dan mengusulkan pengangkatan hakim. Mekanismenya dilakukan sepenuhnya oleh komisi dan selanjutnya akan menghasilkan shortlisted untuk diserahkan kepada Presiden dan Parlemen untuk dimintakan persetujuan. ${ }^{29}$ Mempunyai kewenangan inisiator anggaran (budgeting) terhadap badan peradilan. Melakukan tindakan korektif melalui pendisiplinan hakim sampai dengan mengusulkan pemberhentian hakim. ${ }^{30}$

\section{Afrika Selatan}

Pada konstitusi Afrika Selatan, pengaturan mengenai kekuasaan kehakiman diatur di dalam Chapter 8 dengan judul "Courts and Administration of justice". Di dalam konstitusi Afrika Selatan independensi peradilan menjadi peletak dasar penyelenggaraan kekuasaan kehakiman. Konstitusi menegaskan "the courts are independent and subject only to the Constitution and the law". Jaminan independensi tersebut menegaskan bahwa tidak ada satupun organ negara yang dapat mengintervensi fungsi peradilan (no person or organ of state may interfere with the functioning of the courts). ${ }^{31}$

Pengaturan organ sejenis Judicial Council di Afrika Selatan, diatur pada bab yang sama dengan penamaan Judicial Services Commission (JSC). Faktor pendorong kelahiran organ ini dipicu oleh dua faktor. Pertama, berakhirnya rezim politik "apharteid". Rezim rasialis antara kulit hitam dan kulit putih membawa pengaruh besar terhadap kekuasaan kehakiman di Afrika Selatan. Di bawah rezim rasialisme, hakim hanya bisa dijabat oleh orang kulit putih. Kedua, dipicu oleh besarnya eksklusivisme pemerintah dalam sistem pengangkatan dan pemberhentian hakim. ${ }^{32}$ Konsekuensi logisnya, reformasi konstitusi di tahun 1996 mengatur pelembagan JSC dalam batang tubuh konstitusi.

${ }^{29}$ Latin America Regional Forum, Appointment, Control and Removal of Judges in the Region, Op. Cit.. hlm. 3.

${ }^{30}$ Pasal 114 Konstitusi Argentina 1994.

31 Pasal 165 ayat (2) dan (3), Konstitusi Afrika Selatan 2012.

32 Yonatan T. Fessha, Constitutional Court Appointment: The South African Process", Working Papper, Institute of Intergovernmental Relations School of Policy Studies, Queen's University, 2010, hlm. 1-2. 
Komposisi keanggotaan JSC terdiri dari 23 orang komisioner dari berbagai macam golongan. 3 di antaranya representasi dari kalangan hakim. Sebagaimana terdiri dari konstitusi (chief justice constitutional court), hakim agung (President of Superme Court), hakim pengadilan (Judge President high court of south Africa). 1 dari kabinet pemerintah yang berasal dari menteri kehakiman. 4 orang dari praktisi hukum yang berasal dari kalangan advokat, dan 6 orang dari parlemen yang tiga di antaranya berasal dari partai oposisi pemerintah. 4 orang berasal dari kalangan senator dari (National Council of Provinces), 1 orang berasal dari akademisi, dan 4 orang diangkat oleh presiden berdasarkan persetujuan parlemen. ${ }^{33}$ Jika dilihat dari komposisi keanggotaanya yang berasal dari beragam golongan (partisan), jumlah keanggotaannya ganjil, pengambilan keputusan bersifat kolektif kolegial dan tidak tunduk pada political will presiden, maka JSC merupakan komisi negara independen.

JSC mempunyai otoritas tunggal sebagai organ yang berwenang dalam pengangkatan dan pemberhentian hakim. Semua kategorisasi hakim di dalam kekuasaan kehakiman diusulkan oleh JSC dengan merit sistem. Misalnya saja hakim konstitusi. JSC melakukan seleksi dan menyiapkan shortlisted calon hakim konstitusi untuk dimintakan persetujuan oleh Presiden, parlemen dan hakim agung. Untuk hakim agung, Presiden mengangkat hakim agung atas rekomendasi dari JSC. Begitupun untuk kategorisasi hakim lainnya yang semuanya berasal dari rekomendasi JSC. Begitu juga pemberhentian, semua hakim diberhentikan oleh JSC setelah menemukan pelanggaran kode etik, atau melakukan perbuatan pidana. ${ }^{34}$

\section{Mongolia}

Pada Konstitusi Mongolia, pengaturan tentang kekuasaan kehakiman diatur pada Part IV dengan penamaan "The Judiciary". Sebagai negara demokratis, Mongolia menjamin kemerdekaan kekuasaan kehakiman (independent of judiciary) dalam batang tubuh konstitusinya (constitutionally based power). Pasal 49 ayat (1) Konstitusi Mongolia menegaskan "Judges are independent and subject only to the law". 35

\footnotetext{
33 Pasal 178 Konstitusi Afrika Selatan 2012

34 Pasal 177 Konstitusi Afrika Selatan 2012

35 Pasal 49 ayat (1) Konstitusi Mongolia 2001
} 
Pengaturan organ sejenis Komisi Yudisial (judicial council) di Mongolia mendapatkan porsinya melalui konstitusi (constitutional importance) dengan penamaan Judicial General Council (JGC). ${ }^{36}$ Faktor pendorong kelahiran JGC dipicu oleh perubahan konfigurasi politik dari rezim komunis bergeser ke arah rezim demokratis. Pergeseran konfigurasi politik ini memberi dampak secara langsung terhadap perubahan sistem politik, pemerintahan, dan peradilan yang dulunya berada dibawah rezim komunis hampir selama 70 tahun. ${ }^{37}$

Pergeseran konfigurasi politik ini mendorong perubahan konstitusi Mongolia di 1992. Salah satu kesepakatan politik yang ditempuh pemerintahan Mongolia pasca amandemen konstitusi ialah mendorong percepatan "Legal Reform Program" yang dilakukan sampai di 1998, kemudian dilanjutkan dengan "Strategic Plan for the Justice System of Mongolia" pada 2000. Salah satu tujuan utamanya ialah menjamin kemerdekaan kekuasaan kehakiman. ${ }^{38}$ Buah reformasi peradilan Mongolia mendorong lahirnya JGC yang bertujuan untuk mengawal dan menjamin independensi peradilan. ${ }^{39}$

Komposisi keanggotaan JGC tidak diatur dalam level konstitusi, melainkan diatur pada level undang-undang. Jika dilihat dari model kelembagaan, GCC telah melewati tiga fase bentuk kelembagaan. Hal ini disebabkan oleh karena program percepatan reformasi peradilan yang dilakukan Mongolia berimbas pada posisi karakteristik kelembagaan JGC. Di fase 1993-2002, JGC merupakan perpanjangtangan pemerintah atau eksekutif. Di 2002-2012, JGC berubah bentuk menjadi bagian dari kekuasaan kehakiman yang merupakan perpanjang tangan Mahkamah Agung (MA). Terhitung mulai 2013, JGC berubah bentuk menjadi Komisi Negara Independen yang terpisah dari kekuasaan eksekutif, legislatif, dan yudikatif. Komposisi keanggotaannya terdiri dari lima orang komisioner. Tiga di antaranya berlatar belakang hakim, satu perwakilan dari profesi advokat, dan satu orang dari Kementerian Kehakiman. ${ }^{40}$

${ }^{36}$ Pasal 49 ayat (3) Konstitusi Mongolia 2001.

${ }^{37}$ Heike Gramckow dan Frances Allen, Justice Sector Reform in Mongolia: Looking Back, Looking Forward, Justice and Development Working Paper Series No. 65990, Legal Vice Presidency The World Bank, Whasington DC, 2011, hlm 1 .

38 Ibid., hlm. 2.

${ }^{39}$ Pasal 49 ayat (3) Konstitusi Mongolia 2001.

${ }^{40}$ http://eng.judcouncil.mn/composition.html, diakses pada tanggal 15 November 2016, Pukul 16.00 WIB. 
Jika dilihat dari komposisi keanggotaanya yang bersifat partisan, jumlah komisionernya ganjil, tidak tunduk pada politicall will pemerintah atau presiden, maka GCC merupakan Komisi Negara Independen (independent agency). Perihal kewenangannya konstitusi Mongolia memberikan kewenangan atributif dalam hal mengusulkan pengangkatan hakim. ${ }^{41}$ Begitu juga dalam pengangkatan hakim agung, yang diusulkan oleh JGC untuk setujui oleh parlemen dan disahkan secara seremonial oleh Presiden. ${ }^{42}$ Sejak tahun 2013 perubahan model kelembagaan menjadi organ negara independen berimplikasi langsung terhadap kewenangannya. Melalui perintah undang-undang (legislatively based power), JGC menjadi administrator independen terhadap kekuasaan kehakiman. Termasuk promosi, mutasi, dan pendisiplinan sampai inisiator anggaran (budgeting) terhadap kekuasaan kehakiman.

\section{Analisis Perbandingan dengan Komisi Yudisial RI}

\section{Komisi Yudisial RI}

Amendemen UUD di era transisi (1999-2002) menempatkan jaminan independensi peradilan dalam Pasal 24 UUD 1945 pasca amandemen. Pasal 24 UUD menyatakan “Kekuasaan Kehakiman merupakan kekuasaan yang merdeka untuk menyelenggarakan peradilan guna menegakkan hukum dan keadilan". ${ }^{43}$ Pengaturan organ sejenis judicial council diatur dalam Pasal 24B UUD 1945 dengan penamaan Komisi Yudisial (KY). Faktor pendorong kelahiran KY dipengaruhi oleh 4 faktor. Pertama, akibat pergeseran konfigurasi politik rezim pemerintahan dari yang sifatnya otoritarian kemudian bergerak ke arah yang lebih demokratis. Pergeseran konfigurasi politik ini menuntut performa kekuasaan kehakiman yang lebih independen, transparan, dan akuntabel.

Kedua, akibat gejala reaksional atas praktik politisasi jabatan hakim yang kerap mendapatkan intervensi pemerintah. Gejala ini ditandai oleh pengalaman di era demokrasi terpimpin dan orde baru. Ketiga, pengaruh trend atau globalisasi organ negara sejenis Judicial Council yang telah diadopsi oleh negara-negara Uni

\footnotetext{
41 Pasal 49 ayat (4) Konstitusi Mongolia 2001.

42 Pasal 51 ayat (2) Konstitusi Mongolia 2001.

43 Pasal 24 UUD 1945 Pasca Amandemen
} 
Eropa. Harus diakui Italia dan Prancis menjadi salah satu alternatif model percontohan Judicial Council di berbagai negara.

Keempat, ketiadaan organ yang dapat menjadi penghubung antara aktor kekuasaan kehakiman dengan masyarakat (juctice seeker) untuk melakukan monitoring secara intensif terhadap proses penyelenggaraan kekuasaan kehakiman. Minimnya efektifitas pengawasan secara internal yang telah ada, mendorong lahirnya Komisi Negara Independen sebagai pengawas etika dan kehormatan hakim secara eksternal.

Komposisi keanggotaan KY tidak diatur melalui level konstitusi. UndangUndang Nomor 18 Tahun 2011 tentang Perubahan Undang-Undang Nomor 22 Tahun 2004 tentang Komisi Yudisial. Pasal 6 menyatakan komposisi keanggotaan KY berjumlah 7 orang. Dua di antaranya mantan hakim, dua orang dari praktisi hukum, dua orang dari akademisi, dan satu orang dari anggota masyarakat. ${ }^{44}$ Jika dilihat dari komposisi keanggotaanya yang bersifat partisan, jumlah komisionernya ganjil, independensi kelembagaannya disebutkan oleh UUD, tidak tunduk pada politicall will Pemerintah atau Presiden, maka KY merupakan Komisi Negara Independen (independent agency).

Perihal kewenangannya KY mempunyai kuasa dalam hal mengusulkan pengangkatan calon Hakim Agung dan menegakkan kehormatan dan keluhuran martabat serta perilaku hakim. Setelah melewati proses ajudikasi konstitusional secara beruntun, saat ini kewenangan KY relatif sangat kecil. Oleh karena itu, studi ini mencoba memetakan beberapa pelemahan kewenangan yang terjadi secara beruntun mulai dari 2006 sampai dengan 2015.

44 Pasal 6 ayat (3) Undang-Undang Nomor 18 Tahun 2011 Perubahan Undang-Undang Nomor 22 Tahun 2004 Tentang Komisi Yudisial. 
Tabel $^{45}$

Pelemahan Kewenangan KY Melalui Ajudikasi Konstitusional

\begin{tabular}{|c|c|c|c|c|}
\hline No. & Putusan & Tahun & $\begin{array}{c}\text { Model } \\
\text { Ajudikasi }\end{array}$ & Pelemahan Kewenangan \\
\hline 1 & $\begin{array}{l}\text { Putusan MK Nomor } \\
005 / \text { PUU-IV/2006. }\end{array}$ & 2006 & MK & $\begin{array}{l}\text { Pembatalan kewenangan } \\
\text { pengawasan terhadap hakim } \\
\text { konstitusi }\end{array}$ \\
\hline 2 & $\begin{array}{l}\text { Putusan MA Nomor } \\
\text { 36/PUU/2011 }\end{array}$ & 2011 & MA & $\begin{array}{l}\text { Pembatalan butir } \\
\text { KY\&MA dode etik } \\
\text { kompetensi dalam wilayah } \\
\text { perilaku hakim }\end{array}$ \\
\hline 3 & $\begin{array}{l}\text { Putusan MK Nomor } \\
\text { 1,2/PUU-XII/ } 2014\end{array}$ & 2013 & MK & $\begin{array}{l}\text { Pembatalan kewenangan } \mathrm{KY} \\
\text { dalam keterlibatan panel ahli } \\
\text { seleksi dan pengawasan hakim } \\
\text { konstitusi }\end{array}$ \\
\hline 4 & $\begin{array}{l}\text { Putusan MK Nomor } \\
\text { 43/PUU-XIII/ } 2015\end{array}$ & 2015 & MK & $\begin{array}{l}\text { Pembatalan kewenangan KY } \\
\text { dalam keterlibatan seleksi dan } \\
\text { pengangkatan hakim karir di } \\
\text { bawah MA }\end{array}$ \\
\hline
\end{tabular}

\section{Perbandingan Model \& Kewenangan Komisi Yudisial RI}

Dari hasil perbandingan analisis di atas, terdapat beberapa titik persamaan antara Komisi Yudisial (KY) RI dengan judicial council di empat negara (Bulgaria, Afrika Selatan, Argentina dan Mongolia). Kecenderungan tersebut dapat dilihat dari jaminan independensi peradilan dan posisi teoritik pelembagaan judicial council dalam level konstitusi, alasan faktor pendorong kelahiran, kemiripan corak kewenangan, dan kemiripan model kelembagaan serta komposisi keanggotaan yang bersifat partisan.

Hasil analisis perbandingan terdapat beberapa titik pembeda antara KY dengan judicial council di Bulgaria, Afrika Selatan, Argentina dan Mongolia. Pertama, dari model komposisi keanggotaan. Meskipun model komposisi keanggotaannya sama-sama bersifat partisan, menariknya masing-masing negara yang menjadi sumber komparisi melibatkan keterwakilan golongan hakim sebagai unsur komisioner judicial council. Berbeda dengan KY di Indonesia. Komposisi keanggotaan KY tidak melibatkan keterwakilan golongan hakim melainkan hanya

45 Penjabaran bentuk pelemahan kewenangan KY dapat dilihat secara utuh pada laporan hasil penelitian ini, Idul Rishan, "Perbandingan Judicial Council: Anotasi terbadap Model dan Kewenangan KY di Indonesia", DPPM UII, Yogyakarta, 2017, hlm. 33-43. 
melibatkan mantan hakim. Pengaturan demikian membuka ruang resistensi yang besar antara lembaga pengawas (KY) dan lembaga yang diawasi (MA dan MK). Tidak heran jika resistensi terhadap kewenangan KY datang dari pelaku utama kekuasaan kehakiman itu sendiri (MA dan MK). Terbukti KY di Indonesia harus melewati fase pelemahan kewenangan secara beruntun melalui ajudikasi konstitusional yang dilakukan oleh MA dan MK.

Kedua, daya jelajah kewenangan KY di Indonesia relatif cukup kecil jika dibandingkan dengan kewenangan judicial council di Bulgaria, Afrika Selatan, Argentina dan Mongolia. Hal ini dibuktikan dengan ketiadaan fungsi dan kewenangan di bidang inisiator anggaran badan peradilan serta promosi dan mutasi para hakim. Ketiga, banyaknya pelemahan kewenangan yang dialami KY secara beruntun justru menempatkan KY dengan corak kewenangan yang limitatif. Hal ini dapat dilihat dari subjek kewenangan yang diatur. Artinya KY di Indonesia hanya mempunyai kewenangan pada jabatan hakim tertentu. Sebagaimana kewenangan KY yang tidak terlibat dalam pengangkatan hakim konstitusi dan pengawasan hakim konstitusi. Berbeda halnya dengan negara yang menjadi sumber komparisi. Subjek kewenangan judicial council mencakup semua jabatan hakim di badan peradilan atau yang melekat pada rezim kekuasaan kehakiman.

Menariknya, judicial council di Bulgaria tidak hanya mengatur hakim sebagai subjek kewenangan judicial council melainkan juga Jaksa yang menjadi kompetensi fungsi dan kewenangan judicial council Bulgaria. Artinya jika dilihat dari segi corak kewenangan, KY di Indonesia mempunyai kewenangan yang relatif sangat kecil jika dibandingkan dengan judicial council di Bulgaria, Afrika Selatan, Argentina dan Mongolia.

Melihat beberapa hasil anotasi di atas, maka diperlukan upaya pembaharuan terhadap model dan kewenangan Komisi Yudisial RI. Salah satu alternatifnya ialah melakukan restrukturisasi terhadap komposisi keanggotaan KY. Alternatif pembaharuan dapat dilakukan dengan revisi UU KY. Pengaturan ulang komposisi keanggotaan KY merupakan bentuk open legal policy pembentuk UU sebagaimana diatur dalam Pasal 24B ayat (4) UUD 1945. Keterwakilan golongan hakim diperlukan untuk mengurangi resistensi antara lembaga pengawas (KY) dan 
lembaga yang diawasi (MA dan MK). Kesetimbangan keterwakilan golongan yang terdiri dari hakim, akademisi, dan praktisi hukum menjadi tools dalam menjaga pilar independensi dan akuntabilitas peradilan.

Pengaturan demikian, dapat menyempurnakan kembali daya jelajah kewenangan KY di Indonesia. Alternatifnya dapat dilakukan dengan mengatur ulang hubungan KY, MA, dan MK, dalam RUU Jabatan Hakim. Setidaknya titik pembaharuan dilakukan dengan membangun konsep shared responsibility dalam pengelolaan manajemen hakim dan badan peradilan. Agar setidaknya, KY di Indonesia dapat berfungsi sebagai legal administer career bagi para hakim, yang terlibat mulai dari pengangkatan, promosi, mutasi, pengawasan sampai dengan pemberhentian hakim.

\section{Penutup}

Berdasarkan hasil komparisi di empat negara (Bulgaria, Afrika Selatan, Argentina dan Mongolia), KY di Indonesia lahir atas kecenderungan faktor pendorong kelahiran yang sama. Titik perbedaanya, pertama; terletak pada segi jumlah dan model keterwakilan golongan dalam komposisi keanggotaan KY. Hanya KY di Indonesia yang tidak melibatkan keterwakilan golongan hakim dalam komposisi keanggotaannya. Kedua, daya jelajah kewenangan KY relatif sangat kecil dan terbatas jika dibandingkan dengan judicial council yang menjadi sumber komparisi. Pembaharuan terhadap model dan kewenangan KY dapat dilakukan dengan restrukturiasi keanggotaan KY dan penguatan kewenangan yang digariskan secara terpadu. Mulai dari pengangkatan, promosi, mutasi, pengawasan, sampai dengan pemberhentian hakim, diatur dan dikelola berdasarkan merit sistem. Artinya, Shared responsibility antara KY, MA, dan MK, dalam manajemen hakim dan badan peradilan, menjadi konsep yang menarik untuk diterapkan.

\section{Daftar Pustaka}

\section{Buku}

Cetak biru Pembaruan Komisi Yudisial 2010-2025, KYRI, Jakarta, 2010.

Huda, Ni'matul, Lembaga Negara Dalam Masa Transisi Demokrasi, UII Press, Yogyakarta, 2007. 
Istanto, F. Sugeng, Penelitian Hukum, CV Ganda, Yogyakarta, 2007.

Komisi Yudisial RI, Studi Perbandingan Komisi Yudisial di Beberapa Negara, Kerja sama dengan JPIP dan USAID, Sekertariat Jenderal KYRI, Jakarta, 2014.

Marzuki, Peter Mahmud, Penelitian Hukum, Kencana Prenada, Media Group, Jakarta, 2005.

Pompe, Sebastian, Runtuhnya Institusi Mahkamah Agung, Lembaga Kajian dan Advokasi Untuk Independensi Peradilan, Jakarta, 2012.

Rishan, Idul, Komisi Yudisial; Suatu Upaya Dalam Mewujudkan Wibawa Peradilan, Genta Press, Yogyakarta, 2013.

Saleh, Imam Anshori, Konsep Pengawasan Kehakiman; Upaya Memperkuat Kewenangan Konstitusional Komisi Yudisial Dalam Pengawasan Peradilan, Setara Press, Malang, 2014.

Soemardjono, Maria, Pedoman Pembuatan Usulan Penelitian; Sebuah Panduan Dasar, Gramedia Pustaka Utama, Jakarta, 1996.

Soemardjono, Maria, "Metodologi Penelitian Ilmu Hukum (Buku Ajar)”, UGM, Yogyakarta, 2007.

Soekanto, Soerjono, Pengantar Penelitian Hukum, UI Press, Jakarta, 1986.

Thohari, Ahsin, Komisi Yudisial \& Reformasi Peradilan, ELSAM, Jakarta, 2004.

Voermans, Wim, Komisi Yudisial di beberapa negara Uni Eropa (Council for the Judiciary in EU Countries), Lembaga Kajian dan Advokasi untuk Independensi Peradilan (LeIP), Jakarta, 1999.

\section{Jurnal, Bunga Rampai, Penelitian dan Website}

Cardenas, Emilio J dan Hector M. Chaver, "Corruption, Accountability and Discipline of Judges in Latin America", Comparative of Analysis of Judicial Corruption, Transparency Internasional; Cambridge University Press, 2007.

Fessha, Yonatan T., Constitutional Court Appointment: The South African Process", Working Papper, Institute of Intergovernmental Relations School of Policy Studies, Queen's University, 2010.

Finkel, Jodi, Judicial Reform in Argentina in The 1990's: How Electoral Incentives Shape Institutional Change, Research, Loyola Marymount University, 2004.

Forum, Latin America Regional, Appointment, Control and Removal of Judges in the Region, LARF-International Bar Association, United Kongdom, 2008.

Garoupa, Nuno dan Tom Ginsburg, “Guarding the Guardians: Judicail Councils and Judicial independence", 2008, John M. Olin Law and Economic Working Paper No. 444, Public Law and Legal Theory Working Paper No. 250, Chicago. 
Gramckow, Heike dan Frances Allen, Justice Sector Reform in Mongolia: Looking Back, Looking Forward, Justice and Development Working Paper Series No.65990, 2011, Legal Vice Presidency The World Bank, Whasington DC.

http:/ / eng.judcouncil.mn/composition.html, Diakses pada tanggal 15 November 2016, Pukul 16.00 WIB.

Institute, Open Society, Judicial Independence in Bulgaria, Europe Project: Monitoring the E.U. Accession Process Judicial Independence

Plascencia, Iveth A., "Judicial Appointments: A Comparative Study of Four Judicial Appointment Models Used by Sovereigns Around the World", Law School Student Scholarship- Seton Hall Law Paper 666, 2013, New Jersey.

Zarr, Gerald, Judicial Strengthening in Bulgaria, Bulgaria Judiciary Project No. 1800249.83, 1998, United Stated Agency for International Development, Sofia Bulgaria

\section{Peraturan Perundang-Undangan}

Undang-Undang Dasar Negara Republik Indonesia Tahun 1945 Pasca Amandemen

Undang-Undang Nomor 22 Tahun 2004 Tentang Komisi Yudisial, Lembaran Negara Republik Indonesia Tahun 2004 Nomor 89, Tambahan Lembaran Negara RI Nomor 4415.

Undang-Undang Nomor 18 Tahun 2011 Tentang Perubahan Atas Undang-Undang Nomor 22 Tahun 2004 Tentang Komisi Yudisial, Lembaran Negara Republik Indonesia Tahun 2011 Nomor 106, Tambahan Lembaran Negara RI Nomor, 5250.

\section{Putusan Lembaga Peradilan}

Lihat Putusan MK Nomor 005/PUU-IV/ 2006.

Lihat Putusan MA Nomor 36/PUU/ 2011

Lihat Putusan MK Nomor 1,2/PUU-XII/2014.

Lihat Putusan MK Nomor 43/PUU-XIII/ 2015

\section{Konstitusi di Berbagai Negara}

Konstitusi Bulgaria Tahun 1991

Konstitusi Argentina Tahun 1994

Konstitusi Afrika Selatan Tahun 2012

Konstitusi Mongolia Tahun 2001 